\title{
Evaluating the effect of rainfall variability on vegetation establishment in a semidesert grassland
}

\author{
Jeffrey S. Fehmi • Guo-Yue Niu • Russell L. Scott • \\ Andrea Mathias
}

Received: 12 December 2012 / Accepted: 10 August 2013 / Published online: 24 August 2013

(C) The Author(s) 2013. This article is published with open access at Springerlink.com

\begin{abstract}
Of the operations required for reclamation in arid and semi-arid regions, establishing vegetation entails the most uncertainty due to reliance on unpredictable rainfall for seed germination and seedling establishment. The frequency of successful vegetation establishment was estimated based on a land surface model driven by hourly atmospheric forcing data, 7 years of eddy-flux data, and 31 years of rainfall data at two adjacent sites in southern Arizona, USA. Two scenarios differing in the required imbibition time for successful germination were evaluated -2 or 3 days availability of sufficient surface moisture. Establishment success was assumed to occur if plants could germinate and if the drying front in the soil did not overtake the growth of seminal roots. Based on our results, vegetation establishment could be expected to fail in $32 \%$ of years. In the worst 10-year span, six of ten plantings would have failed. In the best 10-year span, only one of ten was projected to fail. Across all assessments, at most 3 years in a row failed and 6 years in a row were successful. Funding for reclamation seeding must
\end{abstract}

\section{J. S. Fehmi $(\bowtie)$}

School of Natural Resources and the Environment, University of Arizona, Tucson, AZ 85721, USA

e-mail: jfehmi@email.arizona.edu

G.-Y. Niu • A. Mathias

Biosphere 2-Earth Science, University of Arizona, Tucson, AZ 85721, USA

\section{R. L. Scott}

Southwest Watershed Research Center, USDA-ARS, 2000 E. Allen Road, Tucson, AZ 85719, USA be available to allow reseeding the following year if sufficient amount and timing of rainfall does not occur.

Keywords Southern Arizona - Land reclamation · Grass germination $\cdot$ Seeding failure

\section{Introduction}

The operations required to reclaim arid and semi-arid lands fall into several different categories: modifying topography (slope, contours, and drainage), creating appropriate surface composition (compaction, particle size, and origin of the final surface), and establishing vegetation. Of these categories, establishing vegetation entails the most uncertainty. Vegetation establishment is important for: reducing erosion from both wind and water (Guiterrez and Hernandez 1996; De Baets et al. 2009; Fehmi et al. 2008), improving public perception by reducing the visual impact (Hands and Brown 2002; Svobodova et al. 2012), allowing for productive reuse of the land for wildlife habitat or livestock grazing (e.g., Steinke and Majak 2010), and otherwise reintegrating disturbed lands into the existing landscape. Uncertainty in vegetation establishment comes primarily from reliance on unpredictable rainfall for germination and establishment.

While reliance upon rainfall is not the only option, irrigation is expensive and generally not more successful (Roundy et al. 2001) possibly because a high intensity/long duration of water application is needed to establish plants, and even when plants are established 
with irrigation, they can lack water hardiness and die when the irrigation is eventually removed (Josa et al. 2012). Irrigation can also benefit exotic weeds more than natives (e.g., Banerjee et al. 2006). Natural rainfall can allow the establishment of robust native or nonnative vegetation albeit at densities similar to nearby undisturbed vegetation (e.g., Fehmi and Kong 2012). While in the past non-natives were preferred for their ability to establish in years with limited rainfall, natives are now more recommended due to their known longterm stability, resource value for wildlife, and better public acceptance (D’Antonio and Meyerson 2002). Non-natives are currently less acceptable due to potential economic losses due to their invasions off-site, increases in the ability of reclaimed lands to carry wildfire (McDonald and McPherson 2011), and other negative impacts (Hobbs and Cramer 2008).

To maximize the long-term positive impact of revegetation, a mixed plant community is needed that contains the same ratio of functional groups as a natural community in the same area. In addition to being selfsustaining, diversity increases the resiliency of the plant community to disturbance (Quijas et al. 2010). Where they occur, perennial grasses are often the primary contributors to surface stability and erosion prevention (Guiterrez and Hernandez 1996; De Baets et al. 2009) through their life form which is extensive, low to the ground, and with spreading, fibrous roots near the soil surface.

Cox and Jordan (1983) expected successful establishment of native perennial warm-season grasses only $10 \%$ of the time ( 1 in 10 years) in arid to semi-arid southeastern Arizona, USA. This is similar to the estimates generated by Peters (2000) for central New Mexico. Establishment success for a seedling depends on the seminal root staying ahead of the soil drying front. When native warm-season (C4) grasses commonly planted in the southwestern USA germinate, they are supported by the seminal root (often also called the primary root) until the adventitious roots begin to grow. Because these grasses establish the plant crown near the surface of the soil, adventitious root growth can be suppressed by dry conditions (Hyder et al. 1971).

Other than the predictions mentioned above and research studies that rarely consider more than a few years (e.g., Woods et al. 2012), little work has occurred to better assess the chance of seeding success for arid areas. Other studies have shown that seedling recruitment is not dependent solely on high rainfall years but instead on the amount and distribution of rainfall events (e.g., Peters 2000; Zimmerman et al. 2008; Thapa et al. 2012). Given the advances in both natural history information and in ease of computer modeling, Cox and Jordan's (1983) prediction about southern Arizona should be revisited. Modeling can resolve important management and ecological questions because it allows comparisons that are not possible in the field (Hardegree et al. 2010). The goal of this project is to estimate how frequently native perennial warm-season grasses may be established in southern Arizona using 31 years of historical rainfall event data. It is important to research the likelihood of vegetation establishment to better develop mitigation strategies and to allow appropriate budgeting for them.

\section{Materials and methods}

To estimate the frequency of successful establishment, we simulated soil moisture for a 31-year period using a land surface model. The inputs included detailed longterm precipitation event data, data on movement of moisture through the soil, and data on evaporation from the Santa Rita Experimental Range (described below). These data allowed analysis of moisture at the surface and at each soil layer as roots grew through them. Using real-world data was important because having valid input parameters remains the most difficult aspect of modeling seed germination (Flerchinger and Hardegree 2004), and correctly representing rainfall variability is critical for modeling soil moisture (Laio et al. 2001).

The specific practices selected for analysis included having seeded on 15 May (30 days ahead of the normal start of the monsoon season) onto bare soil in southern Arizona, USA. The seeds (generic native warm-season grasses described below) were assumed to be in the top $0-1 \mathrm{~cm}$ of the soil when the monsoon rains began. This was consistent with broadcast seeding in common use (Peppin et al. 2011). The soil type used in the simulations was a loamy sand because this soil texture was common in the region as well as being the primary soil type on a nearby mineland reclamation site. No existing vegetation was assumed at the time of the seeding (bare soil) which had the simplifying effect of having evaporation to be the primary evapotranspiration loss. Germination and establishment were evaluated over the first 21 days, so competition among seedlings was assumed 
not to have an impact on plant growth or soil moisture in this period.

\section{Rainfall data}

Rainfall data (1980-2010, 31 years) came from gages 5 (31.8152 N, 110.8516 W, 1,163 m asl, $398 \mathrm{~mm}$ average annual precipitation) and $6(31.8137 \mathrm{~N}, 110.8544 \mathrm{~W}$, $1,215 \mathrm{~m}$ asl, $405 \mathrm{~mm}$ average annual precipitation) from the Santa Rita Experimental Range (SRER) which was roughly $45 \mathrm{~km}$ south of Tucson, AZ, USA (http://www. tucson.ars.ag.gov/dap/). The gages are $311 \mathrm{~m}$ apart and record the date, time, amount, and duration of each rainfall event. The gages and their operation were as described in Goodrich et al. (2008). The monsoon rainfall in this region was generally from convective cells which can result in different amounts of rainfall, even over short distances, so the data from each gage were evaluated separately.

Model integrating precipitation and eddy flux data to obtain soil moisture

Seven years (6 January 2004-31 December 2010) of eddy flux data were available, including the following measurements: temperature/relative humidity; photosynthetically active radiation; ground heat flux; soil temperature; precipitation; volumetric soil water content at 5,10, 20, 30, 50, 70, 100, and $130 \mathrm{~cm}$ depths; wind velocity vector; sonic temperature and concentrations of water vapor; and carbon dioxide measurements (Scott et al. 2009; hereafter, flux tower data). The measurements were from the Santa Rita Mesquite Savanna site which was also located on the SRER (31.8214 N, $110.8661 \mathrm{~W}, 1,120 \mathrm{~m}$ asl). The soils at the site are uniform sandy loams.

To model the expected soil moisture from the 31 years (1980-2010) of precipitation data, we ran a land surface model, which was driven by hourly atmospheric forcing data. We calibrated the model's hydraulic parameters to match the observed soil moisture and surface energy and water fluxes from the flux tower data and then applied the optimized parameters to the 31-year precipitation data set.

The atmospheric forcing data to drive the model included: hourly downward shortwave and longwave radiation fluxes, precipitation, air temperature, humidity, pressure, and wind speed. These data were computed as distance-weighted averages of those at four surrounding points of the 0.125 degree, gridded North American Land Data Assimilation System (NLDAS) surface atmospheric data (Mitchell et al. 2004). To check the accuracy of the NLDAS data, sensitivity experiments during the calibration period were conducted by replacing an individual variable of the flux tower data with that of the NLDAS data. Through this exercise, we found that NLDAS data overestimated wintertime precipitation and had the largest effect on the simulation of soil moisture, while other variables had less effect. We then replaced the NLDAS precipitation with the rainfall from gages 5 and 6 from the Santa Rita Experimental Range. Thus, for the period from 1980-2003, we ran the model using the optimized hydraulic parameters and the NLDAS atmospheric forcing with its rainfall data being replaced with data from gages 5 and 6 .

The Noah land surface model was used in this study with multiple options for parameterization schemes of various land surface processes (Niu et al. 2011). There were only four soil layers in the standard model that was coupled with the Weather Research and Forecast model. In this study, to match the flux tower measurement depths, we divided the model soil into 16 soil layers (breaking at 2.5, 5, 10, 15, 20, 25, 30, 45, 50, 60, $70,90,100,120,130$, and $200 \mathrm{~cm}$ ). The model solved the one-dimensional Richards' equation to account for redistribution of soil moisture among these layers through diffusion and percolation processes. At the 2m model bottom, we used a groundwater recharge rate, which was provided by a simple groundwater model, as the lower boundary condition to ensure a more precise simulation.

The soil hydraulic parameters for loamy sand were set up through a look-up table using the Clapp-Hornberger relationship (Clapp and Hornberger 1978). However, the amplitudes of the modeled soil moisture for most of the deep soil layers were too small to match observations, indicating the diffusion processes of soil water are relatively weak. The constant value $1.5 \times 10^{-8} \mathrm{~m} / \mathrm{s}$ was added to the diffusivity which resulted in comparable soil moisture for all measurement depths. The enhanced diffusivity accounted for extra diffusion of vaporized soil water under dry and hot conditions (Niu et al. 1997).

\section{Assessment of germination}

Our analysis assumed that the native, warm-season (C4) grass seeds were in the soil from $0-1 \mathrm{~cm}$ deep as suggested by Roundy et al. (1997), which corresponds 
well to visual observations of seed depth after broadcast seeding on this soil type in this area. The seeds were assumed to remain available until they germinate rather than experiencing any other fate such as being eaten, buried, blown, or washed off site, etc. All seeds were assumed to germinate when exposed to suitable monsoon conditions (per Abbott and Roundy 2003). Wetting events that did not result in germination were assumed to cause no injury to these warm-season perennial grass seeds (Roundy et al. 1997). Germinating conditions that occurred before 15 May were not considered because this was before we assumed planting to occur. Germinating conditions that occurred after 30 September were assumed to result in seeding failure due to the lack of suitable growing conditions (cool weather) in October.

Two scenarios were evaluated for each of the rain gages - 2 days of suitable conditions resulting in germination and 3 days of suitable conditions resulting in germination. Plants were counted as germinated if the water volume in the $0-2.5 \mathrm{~cm}$ layer stayed above $0.09 \mathrm{~cm}^{3} / \mathrm{cm}^{3}$ for 2 or 3 days (analyzed separately). This should be a conservative but general estimate for germination. An intermediate value for water volume (roughly twice the wilting point, $0.046 \mathrm{~cm}^{3} / \mathrm{cm}^{3}$, Laio et al. 2001) was chosen because the $0-2.5-\mathrm{cm}$ layer dries quickly, but seeds can germinate if the relative humidity remains high at the soil surface (Wuest 2007). This generally fits with the observation of Roundy et al. (1997) that the surface soil becomes too dry within 1 day or less of the cessation of a storm.

The 2-day scenario was a more cautious interpretation of the available data on seed germination. Most warm-season perennial grasses germinate within 1.5 to 4 days of saturation of the surface soil at summer temperatures (Roundy and Biedenbender 1996). The 2-day scenario supported native warm-season grass species like Bouteloua curtipendula (Sideoats grama) which germinated and emerged within 2 days of suitable conditions - 50 \% in 1 day (Simanton and Jordan 1986). The authors considered this fast germination. Another study observed emergence of $B$. curtipendula beginning in $18 \mathrm{~h}$ and ending after 3 days (Frasier et al. 1985). While different authors have tested germination in different ways, most typically, the reported times were for saturated soil and our standard was dryer than that. Our 2-day germination scenario typically corresponded to one large or two medium-sized events.

The 3-day scenario was a more lenient estimate of the time needed for germination and corresponds more closely to available data on native warm-season grass germination. Smith et al. (2000) found Digitaria californica (Arizona cottontop) required a minimum of $140 \mathrm{~mm}$ of water in a 3-day period for $50 \%$ emergence. Wilson and Briske (1979) found Bouteloua gracilis (Blue grama) needed wet conditions for 2-4 days to germinate. After 2.3 days in wet field conditions, Abbott and Roundy (2003) found B. curtipendula had $90 \%$ germination; Leptochloa dubia (Green sprangletop) had $75 \%$; D. californica had $70 \%$, and Eragrostis intermedia (Plains lovegrass) had $45 \%$. Our 3-day germination scenario typically corresponded with $2-2.5$ days of rain.

Assessment of survival after germination:

Our analysis of survival was based on seminal root growth. Germinated plants die when seminal root growth does not keep up with the drying front in the soil which makes soil moisture the primary controlling factor for seedling mortality (Carren et al. 1987; Zimmerman et al. 2008; Perring and Hovenden 2012; Thapa et al. 2012). This process was important for 2-3 weeks after germination when 2-4 days of additional moisture was needed at the soil surface for development of the plant crown and adventitious roots (Carren et al. 1987; Roundy et al. 1993). The drying front was defined as the wilting point $\left(0.046 \mathrm{~cm}^{3} / \mathrm{cm}^{3}\right)$ for a loamy sand (Laio et al. 2001).

The rate of $0.8 \mathrm{~cm}$ root elongation per day was chosen as a conservative estimate based on several studies of native warm-season perennial grasses. For B. gracilis, the seminal root grew $0.79 \mathrm{~cm}$ per day for the first 2 weeks (Carren et al. 1987). B. curtipendula averaged about $0.8 \mathrm{~cm}$ per day of seminal root elongation during the first 15 days (Roundy et al. 1993). In another study, Simanton and Jordan (1986) found an elongation rate of $0.97 \mathrm{~cm}$ per day for the first 7 days for $B$. curtipendula. Using the modeled soil moisture, root elongation was evaluated for 19 days after germination. This was when the seminal root reaches $15 \mathrm{~cm}$ soil depth. If sufficient water were available, plants may have initiated adventitious roots during our 19-day evaluation, but we evaluated soil moisture for the whole soil column and dryness below the wilting point would have affected adventitious roots as well as seminal roots. In our assessment, we checked the simulated water content of the soil column from the surface to the depth of the seminal root, and if the whole column was below the wilting point, the seeding was considered to have failed. 
Table 1 Evaluation of plants taking 2 days to germinate at the gage 5 site
Numbers at or below the wilting point $\left(0.046 \mathrm{~cm}^{3} / \mathrm{cm}^{3}\right)$ for this soil type are in bold. Of the 31 years evaluated, 20 years had successful establishment in the first 19 days after germination

${ }^{\mathrm{a}}$ Too little rain, hits wilting point at 2.5 to $5.0 \mathrm{~cm}$

${ }^{\mathrm{b}}$ Too little rain, hits wilting point at 5.0 to $10.0 \mathrm{~cm}$

${ }^{\mathrm{c}}$ Too little rain, hits wilting point at surface to $2.5 \mathrm{~cm}$

${ }^{\mathrm{d}}$ No germination

\begin{tabular}{|c|c|c|c|c|c|c|}
\hline \multirow[b]{2}{*}{ Success/failure } & \multirow[b]{2}{*}{ Year } & \multirow[b]{2}{*}{$\begin{array}{l}\text { Germination } \\
\text { date }\end{array}$} & \multicolumn{4}{|c|}{$\begin{array}{l}\text { Minimum soil moisture } \mathrm{cm}^{3} / \mathrm{cm}^{3} \text { during root } \\
\text { elongation through zone }\end{array}$} \\
\hline & & & $\begin{array}{l}\text { Surface to } \\
2.5 \mathrm{~cm}\end{array}$ & $\begin{array}{l}2.5 \text { to } \\
5.0 \mathrm{~cm}\end{array}$ & $\begin{array}{l}5.0 \text { to } \\
10.0 \mathrm{~cm}\end{array}$ & $\begin{array}{l}10.0 \text { to } \\
15.0 \mathrm{~cm}\end{array}$ \\
\hline & 1980 & 14 Aug & 0.051 & 0.049 & 0.053 & 0.055 \\
\hline & 1981 & $11 \mathrm{Jul}$ & 0.119 & 0.118 & 0.082 & 0.084 \\
\hline \multirow[t]{4}{*}{ Failed $^{\mathrm{a}}$} & 1982 & $8 \mathrm{Jul}$ & 0.048 & 0.045 & 0.058 & 0.099 \\
\hline & 1983 & $12 \mathrm{Jul}$ & 0.067 & 0.053 & 0.055 & 0.049 \\
\hline & 1984 & 30 Jun & 0.064 & 0.081 & 0.073 & 0.078 \\
\hline & 1985 & $21 \mathrm{Jul}$ & 0.073 & 0.060 & 0.075 & 0.083 \\
\hline Failed $^{\mathrm{b}}$ & 1986 & $17 \mathrm{Jul}$ & 0.060 & 0.057 & 0.041 & 0.043 \\
\hline Failed $^{\mathrm{b}}$ & 1987 & 22 May & 0.058 & 0.052 & 0.039 & 0.037 \\
\hline \multirow[t]{3}{*}{ Failed $^{\mathrm{c}}$} & 1988 & $11 \mathrm{Jul}$ & 0.044 & 0.040 & 0.052 & 0.107 \\
\hline & 1989 & $28 \mathrm{Jul}$ & 0.085 & 0.076 & 0.083 & 0.083 \\
\hline & 1990 & $9 \mathrm{Jul}$ & 0.129 & 0.095 & 0.133 & 0.136 \\
\hline Failed $^{\mathrm{c}}$ & 1991 & $31 \mathrm{Jul}$ & 0.035 & 0.033 & 0.041 & 0.067 \\
\hline \multirow[t]{3}{*}{ Failed $^{\mathrm{b}}$} & 1992 & $9 \mathrm{Jul}$ & 0.088 & 0.065 & 0.044 & 0.054 \\
\hline & 1993 & 4 Aug & 0.141 & 0.113 & 0.072 & 0.082 \\
\hline & 1994 & $4 \mathrm{Sep}$ & 0.060 & 0.050 & 0.089 & 0.076 \\
\hline \multirow[t]{6}{*}{ Failed $^{\mathrm{c}}$} & 1995 & $22 \mathrm{Aug}$ & 0.046 & 0.049 & 0.039 & 0.040 \\
\hline & 1996 & $4 \mathrm{Jul}$ & 0.072 & 0.078 & 0.094 & 0.070 \\
\hline & 1997 & 19 Aug & 0.053 & 0.064 & 0.071 & 0.080 \\
\hline & 1998 & $6 \mathrm{Jul}$ & 0.129 & 0.098 & 0.072 & 0.085 \\
\hline & 1999 & $27 \mathrm{Jul}$ & 0.090 & 0.067 & 0.065 & 0.074 \\
\hline & 2000 & 21 Jun & 0.059 & 0.090 & 0.091 & 0.090 \\
\hline Failed $^{\mathrm{c}}$ & 2001 & 5 Aug & 0.034 & 0.064 & 0.068 & 0.068 \\
\hline \multirow[t]{2}{*}{ Failed $^{c}$} & 2002 & $18 \mathrm{Jul}$ & 0.045 & 0.052 & 0.103 & 0.087 \\
\hline & 2003 & $27 \mathrm{Jul}$ & 0.099 & 0.111 & 0.082 & 0.082 \\
\hline \multirow[t]{5}{*}{ Failed $^{\mathrm{c}}$} & 2004 & $15 \mathrm{Jul}$ & 0.036 & 0.047 & 0.058 & 0.089 \\
\hline & 2005 & 6 Aug & 0.116 & 0.091 & 0.101 & 0.082 \\
\hline & 2006 & $28 \mathrm{Jul}$ & 0.094 & 0.094 & 0.079 & 0.069 \\
\hline & 2007 & $21 \mathrm{Jul}$ & 0.064 & 0.066 & 0.076 & 0.089 \\
\hline & 2008 & $13 \mathrm{Jul}$ & 0.051 & 0.047 & 0.067 & 0.071 \\
\hline \multirow[t]{2}{*}{ Failed $^{\mathrm{d}}$} & 2009 & No germ & & & & \\
\hline & 2010 & $31 \mathrm{Jul}$ & 0.075 & 0.056 & 0.054 & 0.054 \\
\hline
\end{tabular}

\section{Results}

The average germination date for the gage 5 2-day scenario was 20 July (Table 1), and for the 3-day scenario, it was 1 August (Table 2). The average germination dates for gage 6 2-day scenario was 19 July (Table 3), and for the 3-day scenario, it was 27 July (Table 4). In most years, there was little difference in germination date and success among the gages and the scenarios, but in a few years there were substantive differences among the gages and treatment germination dates (Fig. 1). In 2001, the expected germination in the 3-day evaluation of gage 5 was 111 days later than the 2-day evaluation of gage 6 .

For the gage 5 two-day scenario (Table 1), $35 \%$ of the years failed to have successful establishment, and $29 \%$ failed for the 3-day scenario (Table 2). For the gage 6 two-day scenario (Table 3), $29 \%$ of the years failed, and $35 \%$ failed for the 3-day scenario (Table 4). This gives an average failure rate of $32 \%$. The years 
Table 2 Evaluation of plants taking 3 days to germinate at the gage 5 site
Numbers at or below the wilting point $\left(0.046 \mathrm{~cm}^{3} / \mathrm{cm}^{3}\right)$ for this soil type are in bold. Of the 31 years evaluated, 22 years had successful establishment in the first 19 days after germination

${ }^{\mathrm{a}}$ Too little rain, hits wilting point at 2.5 to $5.0 \mathrm{~cm}$

${ }^{\mathrm{b}}$ Too little rain, hits wilting point at 5.0 to $10.0 \mathrm{~cm}$

${ }^{\mathrm{c}}$ Too little rain, hits wilting point at surface to $2.5 \mathrm{~cm}$

${ }^{\mathrm{d}}$ Germination too late in season

${ }^{\mathrm{e}}$ No germination

\begin{tabular}{|c|c|c|c|c|c|c|}
\hline \multirow[b]{2}{*}{$\begin{array}{l}\text { Success/ } \\
\text { failure }\end{array}$} & \multirow[b]{2}{*}{ Year } & \multirow[b]{2}{*}{$\begin{array}{l}\text { Germination } \\
\text { date }\end{array}$} & \multicolumn{4}{|c|}{$\begin{array}{l}\text { Minimum soil moisture } \mathrm{cm}^{3} / \mathrm{cm}^{3} \text { during root elongation } \\
\text { through zone }\end{array}$} \\
\hline & & & $\begin{array}{c}\text { Surface to } \\
2.5 \mathrm{~cm}\end{array}$ & $\begin{array}{l}2.5 \text { to } \\
5.0 \mathrm{~cm}\end{array}$ & $\begin{array}{l}5.0 \text { to } \\
10.0 \mathrm{~cm}\end{array}$ & $\begin{array}{l}10.0 \text { to } \\
15.0 \mathrm{~cm}\end{array}$ \\
\hline \multirow[t]{3}{*}{ Failed $^{\mathrm{a}}$} & 1980 & $15 \mathrm{Aug}$ & 0.048 & 0.043 & 0.053 & 0.051 \\
\hline & 1981 & $12 \mathrm{Jul}$ & 0.104 & 0.121 & 0.075 & 0.084 \\
\hline & 1982 & $23 \mathrm{Jul}$ & 0.068 & 0.063 & 0.061 & 0.058 \\
\hline \multirow[t]{3}{*}{ Failed $^{\mathrm{a}}$} & 1983 & $13 \mathrm{Jul}$ & 0.064 & 0.044 & 0.055 & 0.046 \\
\hline & 1984 & $19 \mathrm{Jul}$ & 0.091 & 0.103 & 0.098 & 0.096 \\
\hline & 1985 & $22 \mathrm{Jul}$ & 0.070 & 0.060 & 0.100 & 0.077 \\
\hline \multirow[t]{2}{*}{ Failed $^{\mathrm{b}}$} & 1986 & $18 \mathrm{Jul}$ & 0.047 & 0.057 & 0.039 & 0.043 \\
\hline & 1987 & 6 Aug & 0.066 & 0.085 & 0.068 & 0.072 \\
\hline \multirow[t]{4}{*}{ Failed $^{c}$} & 1988 & $12 \mathrm{Jul}$ & 0.035 & 0.040 & 0.085 & 0.108 \\
\hline & 1989 & $29 \mathrm{Jul}$ & 0.074 & 0.076 & 0.083 & 0.078 \\
\hline & 1990 & $10 \mathrm{Jul}$ & 0.101 & 0.095 & 0.133 & 0.130 \\
\hline & 1991 & 10 Aug & 0.055 & 0.071 & 0.066 & 0.058 \\
\hline \multirow[t]{4}{*}{ Failed $^{\mathrm{c}}$} & 1992 & $13 \mathrm{Jul}$ & 0.046 & 0.042 & 0.044 & 0.064 \\
\hline & 1993 & $5 \mathrm{Aug}$ & 0.141 & 0.097 & 0.072 & 0.086 \\
\hline & 1994 & $5 \mathrm{Sep}$ & 0.049 & 0.050 & 0.081 & 0.076 \\
\hline & 1995 & $30 \mathrm{Sep}$ & 0.064 & 0.062 & 0.053 & 0.051 \\
\hline \multirow[t]{5}{*}{ Failed $^{\mathrm{c}}$} & 1996 & $16 \mathrm{Jul}$ & 0.042 & 0.043 & 0.048 & 0.051 \\
\hline & 1997 & $16 \mathrm{Sep}$ & 0.054 & 0.062 & 0.062 & 0.052 \\
\hline & 1998 & $7 \mathrm{Jul}$ & 0.105 & 0.098 & 0.072 & 0.125 \\
\hline & 1999 & $28 \mathrm{Jul}$ & 0.085 & 0.067 & 0.065 & 0.074 \\
\hline & 2000 & 25 Jun & 0.055 & 0.071 & 0.077 & 0.075 \\
\hline \multirow[t]{3}{*}{ Failed $^{\mathrm{b}}$} & 2001 & $10 \mathrm{Oct}$ & 0.057 & 0.051 & 0.041 & 0.039 \\
\hline & 2002 & $25 \mathrm{Jul}$ & 0.106 & 0.078 & 0.075 & 0.085 \\
\hline & 2003 & $28 \mathrm{Jul}$ & 0.096 & 0.123 & 0.078 & 0.082 \\
\hline \multirow[t]{5}{*}{ Failed $^{\mathrm{a}, \mathrm{d}}$} & 2004 & 17 Aug & 0.049 & 0.044 & 0.044 & 0.039 \\
\hline & 2005 & 7 Aug & 0.103 & 0.091 & 0.092 & 0.082 \\
\hline & 2006 & $29 \mathrm{Jul}$ & 0.096 & 0.083 & 0.074 & 0.067 \\
\hline & 2007 & $22 \mathrm{Jul}$ & 0.056 & 0.063 & 0.081 & 0.083 \\
\hline & 2008 & $22 \mathrm{Jul}$ & 0.099 & 0.071 & 0.049 & 0.062 \\
\hline \multirow[t]{2}{*}{ Failed $^{\mathrm{e}}$} & 2009 & No germ & & & & \\
\hline & 2010 & $1 \mathrm{Aug}$ & 0.057 & 0.051 & 0.049 & 0.054 \\
\hline
\end{tabular}

where establishment failed do not always overlap. For gage 5 , there were 6 years where the seeding failed for both scenarios (19\% failure rate), and for gage 6 , there were only 4 years (13\% failure rate) where it failed for both scenarios (Table 5). These same 4 years also failed for gage 5, giving a failure rate common across both gages and both scenarios of $13 \%$.

The worst 10-year span was gage 5 for the 2-day scenario where between 1986 and 1995, six of ten plantings would have failed (Table 1). The best 10- year span was gage 6 for the 3-day scenario where, between 1998 and 2007, only one of ten was projected to fail (Table 4). At most, 3 years in a row failed, and 6 years in a row were successful.

\section{Discussion}

Our modeling results showed six times more potential for seeding success $(68 \%)$ than was expected from the 
Table 3 Evaluation of plants taking 2 days to germinate at the gage 6 site
Numbers at or below the wilting point $\left(0.046 \mathrm{~cm}^{3} / \mathrm{cm}^{3}\right)$ for this soil type are in bold. Of the 31 years evaluated, 22 years had successful establishment in the first 19 days after germination

${ }^{\mathrm{a}}$ Too little rain, hits wilting point at 2.5 to $5.0 \mathrm{~cm}$

${ }^{\mathrm{b}}$ Too little rain, hits wilting point at 5.0 to $10.0 \mathrm{~cm}$

${ }^{\mathrm{c}}$ Too little rain, hits wilting point at surface to $2.5 \mathrm{~cm}$

${ }^{\mathrm{d}}$ No germination

${ }^{\mathrm{e}}$ Also failed 5 May which is outside the planting window

\begin{tabular}{|c|c|c|c|c|c|c|}
\hline \multirow[b]{2}{*}{$\begin{array}{l}\text { Success/ } \\
\text { failure }\end{array}$} & \multirow[b]{2}{*}{ Year } & \multirow[b]{2}{*}{$\begin{array}{l}\text { Germination } \\
\text { date }\end{array}$} & \multicolumn{4}{|c|}{$\begin{array}{l}\text { Minimum soil moisture } \mathrm{cm}^{3} / \mathrm{cm}^{3} \text { during root elongation } \\
\text { through zone }\end{array}$} \\
\hline & & & $\begin{array}{l}\text { Surface to } \\
2.5 \mathrm{~cm}\end{array}$ & $\begin{array}{l}2.5 \text { to } \\
5.0 \mathrm{~cm}\end{array}$ & $\begin{array}{l}5.0 \text { to } \\
10.0 \mathrm{~cm}\end{array}$ & $\begin{array}{l}10.0 \text { to } \\
15.0 \mathrm{~cm}\end{array}$ \\
\hline & 1980 & 14 Aug & 0.055 & 0.051 & 0.055 & 0.057 \\
\hline & 1981 & $11 \mathrm{Jul}$ & 0.117 & 0.122 & 0.095 & 0.094 \\
\hline \multirow[t]{4}{*}{ Failed $^{\mathrm{a}}$} & 1982 & $8 \mathrm{Jul}$ & 0.048 & 0.044 & 0.057 & 0.102 \\
\hline & 1983 & $12 \mathrm{Jul}$ & 0.065 & 0.051 & 0.053 & 0.048 \\
\hline & 1984 & 30 Jun & 0.069 & 0.084 & 0.075 & 0.095 \\
\hline & 1985 & $16 \mathrm{Jul}$ & 0.063 & 0.118 & 0.081 & 0.102 \\
\hline Failed $^{\mathrm{b}}$ & 1986 & $17 \mathrm{Jul}$ & 0.057 & 0.054 & 0.042 & 0.043 \\
\hline Failed $^{\mathrm{b}}$ & 1987 & 22 May & 0.053 & 0.048 & 0.037 & 0.036 \\
\hline \multirow[t]{4}{*}{ Failed $^{\mathrm{a}}$} & 1988 & $11 \mathrm{Jul}$ & 0.047 & 0.042 & 0.055 & 0.107 \\
\hline & 1989 & $28 \mathrm{Jul}$ & 0.083 & 0.076 & 0.083 & 0.067 \\
\hline & 1990 & $10 \mathrm{Jul}$ & 0.132 & 0.098 & 0.135 & 0.137 \\
\hline & 1991 & 9 Aug & 0.071 & 0.071 & 0.063 & 0.063 \\
\hline \multirow[t]{3}{*}{ Failed $^{\mathrm{b}, \mathrm{e}}$} & 1992 & $10 \mathrm{Jul}$ & 0.090 & 0.064 & 0.044 & 0.053 \\
\hline & 1993 & 4 Aug & 0.137 & 0.113 & 0.072 & 0.084 \\
\hline & 1994 & $4 \mathrm{Sep}$ & 0.057 & 0.051 & 0.089 & 0.079 \\
\hline \multirow[t]{6}{*}{ Failed $^{c}$} & 1995 & 22 Aug & 0.041 & 0.044 & 0.036 & 0.040 \\
\hline & 1996 & $4 \mathrm{Jul}$ & 0.060 & 0.072 & 0.092 & 0.067 \\
\hline & 1997 & 19 Aug & 0.051 & 0.062 & 0.071 & 0.080 \\
\hline & 1998 & $6 \mathrm{Jul}$ & 0.125 & 0.096 & 0.072 & 0.082 \\
\hline & 1999 & $27 \mathrm{Jul}$ & 0.095 & 0.067 & 0.062 & 0.068 \\
\hline & 2000 & 24 Jun & 0.066 & 0.071 & 0.084 & 0.081 \\
\hline Failed $^{\mathrm{c}}$ & 2001 & 22 Jun & 0.031 & 0.035 & 0.030 & 0.034 \\
\hline \multirow[t]{7}{*}{ Failed $^{c}$} & 2002 & $18 \mathrm{Jul}$ & 0.044 & 0.051 & 0.100 & 0.087 \\
\hline & 2003 & $27 \mathrm{Jul}$ & 0.095 & 0.107 & 0.080 & 0.077 \\
\hline & 2004 & $30 \mathrm{Jul}$ & 0.065 & 0.070 & 0.048 & 0.056 \\
\hline & 2005 & 6 Aug & 0.092 & 0.091 & 0.101 & 0.083 \\
\hline & 2006 & $28 \mathrm{Jul}$ & 0.094 & 0.094 & 0.078 & 0.069 \\
\hline & 2007 & $21 \mathrm{Jul}$ & 0.064 & 0.067 & 0.076 & 0.089 \\
\hline & 2008 & $13 \mathrm{Jul}$ & 0.051 & 0.047 & 0.067 & 0.070 \\
\hline \multirow[t]{2}{*}{ Failed $^{\mathrm{d}}$} & 2009 & No germ & & & & \\
\hline & 2010 & $31 \mathrm{Jul}$ & 0.075 & 0.056 & 0.054 & 0.054 \\
\hline
\end{tabular}

$10 \%$ estimate by Cox and Jordan (1983) for southern Arizona. While this may show substantial potential for reclamation in most years, there are numerous factors, such as germination response, root growth, and other sources of mortality, that bear further consideration.

The germination periods of 2 or 3 days which we assumed for analysis do not necessarily reflect the full scope of plant responses in real-world situations. For instance, non-germinating rains (not long enough in duration) that cause more than 1 day of adequate soil moisture can reduce seed viability (Emmerich and Hardegree 1996). But less than 1 day of soil moisture before the eventual germinating rain can prime seeds and allow them to germinate faster than unexposed seeds once germinating rains occur (Emmerich and Hardegree 1996). In addition, a small amount of the native grass seed (1-2\%) will not germinate until the second or third germinating rain (Abbott and Roundy 2003) which is also not included in the model. These factors were not included because not enough information was available 
Table 4 Evaluation of plants taking 3 days to germinate at the gage 6 site
Numbers at or below the wilting point $\left(0.046 \mathrm{~cm}^{3} / \mathrm{cm}^{3}\right)$ for this soil type are in bold. Of the 31 years evaluated, 23 years had successful establishment in the first 19 days after germination

${ }^{\mathrm{a}}$ Too little rain, hits wilting point at 2.5 to $5.0 \mathrm{~cm}$

${ }^{\mathrm{b}}$ Too little rain, hits wilting point at 5.0 to $10.0 \mathrm{~cm}$

${ }^{\mathrm{c}}$ Too little rain, hits wilting point at surface to $2.5 \mathrm{~cm}$

${ }^{\mathrm{d}}$ Germinated too late in season for successful establishment

${ }^{\mathrm{e}}$ No germination

\begin{tabular}{|c|c|c|c|c|c|c|}
\hline \multirow[b]{2}{*}{$\begin{array}{l}\text { Success/ } \\
\text { failure }\end{array}$} & \multirow[b]{2}{*}{ Year } & \multirow[b]{2}{*}{$\begin{array}{l}\text { Germination } \\
\text { date }\end{array}$} & \multicolumn{4}{|c|}{$\begin{array}{l}\text { Minimum soil moisture } \mathrm{cm}^{3} / \mathrm{cm}^{3} \text { during root elongation } \\
\text { through zone }\end{array}$} \\
\hline & & & $\begin{array}{c}\text { Surface to } \\
2.5 \mathrm{~cm}\end{array}$ & $\begin{array}{l}2.5 \text { to } \\
5.0 \mathrm{~cm}\end{array}$ & $\begin{array}{l}5.0 \text { to } \\
10.0 \mathrm{~cm}\end{array}$ & $\begin{array}{l}10.0 \text { to } \\
15.0 \mathrm{~cm}\end{array}$ \\
\hline \multirow[t]{3}{*}{ Failed $^{\mathrm{a}}$} & 1980 & $15 \mathrm{Aug}$ & 0.051 & 0.045 & 0.055 & 0.054 \\
\hline & 1981 & $12 \mathrm{Jul}$ & 0.110 & 0.122 & 0.086 & 0.094 \\
\hline & 1982 & $23 \mathrm{Jul}$ & 0.077 & 0.069 & 0.067 & 0.064 \\
\hline \multirow[t]{3}{*}{ Failed $^{\mathrm{a}}$} & 1983 & $13 \mathrm{Jul}$ & 0.060 & 0.043 & 0.053 & 0.046 \\
\hline & 1984 & $1 \mathrm{Jul}$ & 0.066 & 0.077 & 0.075 & 0.112 \\
\hline & 1985 & $20 \mathrm{Jul}$ & 0.099 & 0.078 & 0.081 & 0.085 \\
\hline \multirow[t]{2}{*}{ Failed $^{\mathrm{b}}$} & 1986 & $18 \mathrm{Jul}$ & 0.045 & 0.054 & 0.039 & 0.043 \\
\hline & 1987 & 6 Aug & 0.060 & 0.078 & 0.066 & 0.069 \\
\hline \multirow[t]{4}{*}{ Failed $^{b}$} & 1988 & $12 \mathrm{Jul}$ & 0.037 & 0.042 & 0.092 & 0.115 \\
\hline & 1989 & $29 \mathrm{Jul}$ & 0.075 & 0.076 & 0.083 & 0.063 \\
\hline & 1990 & $10 \mathrm{Jul}$ & 0.105 & 0.098 & 0.135 & 0.128 \\
\hline & 1991 & 10 Aug & 0.055 & 0.071 & 0.061 & 0.060 \\
\hline \multirow[t]{3}{*}{ Failed $^{c}$} & 1992 & $10 \mathrm{Jul}$ & 0.075 & 0.054 & 0.044 & 0.080 \\
\hline & 1993 & $5 \mathrm{Aug}$ & 0.137 & 0.097 & 0.072 & 0.083 \\
\hline & 1994 & $5 \mathrm{Sep}$ & 0.048 & 0.051 & 0.082 & 0.079 \\
\hline Failed $^{\mathrm{d}}$ & 1995 & $30 \mathrm{Sep}$ & 0.065 & 0.063 & 0.056 & 0.057 \\
\hline Failed $^{\mathrm{c}}$ & 1996 & $16 \mathrm{Jul}$ & 0.038 & 0.040 & 0.046 & 0.051 \\
\hline \multirow[t]{7}{*}{ Failed $^{\mathrm{d}}$} & 1997 & $16 \mathrm{Sep}$ & 0.052 & 0.061 & 0.062 & 0.052 \\
\hline & 1998 & $7 \mathrm{Jul}$ & 0.102 & 0.096 & 0.071 & 0.123 \\
\hline & 1999 & $28 \mathrm{Jul}$ & 0.085 & 0.064 & 0.062 & 0.068 \\
\hline & 2000 & 25 Jun & 0.054 & 0.071 & 0.077 & 0.077 \\
\hline & 2001 & $17 \mathrm{Jul}$ & 0.066 & 0.062 & 0.061 & 0.051 \\
\hline & 2002 & $25 \mathrm{Jul}$ & 0.098 & 0.074 & 0.073 & 0.084 \\
\hline & 2003 & $28 \mathrm{Jul}$ & 0.091 & 0.119 & 0.077 & 0.077 \\
\hline \multirow[t]{4}{*}{ Failed $^{\mathrm{c}}$} & 2004 & 17 Aug & 0.044 & 0.041 & 0.042 & 0.038 \\
\hline & 2005 & 7 Aug & 0.103 & 0.091 & 0.092 & 0.083 \\
\hline & 2006 & $29 \mathrm{Jul}$ & 0.096 & 0.083 & 0.074 & 0.067 \\
\hline & 2007 & $22 \mathrm{Jul}$ & 0.056 & 0.063 & 0.081 & 0.083 \\
\hline Failed $^{\mathrm{c}}$ & 2008 & $22 \mathrm{Jul}$ & 0.099 & 0.070 & 0.049 & 0.062 \\
\hline \multirow[t]{2}{*}{ Failed $^{\mathrm{e}}$} & 2009 & No germ & & & & \\
\hline & 2010 & $1 \mathrm{Aug}$ & 0.057 & 0.051 & 0.049 & 0.054 \\
\hline
\end{tabular}

to determine the expected average outcome, and the magnitude of the effect on reclamation success would likely be small.

The period after germination is similarly more complex than our model represents, although we have incorporated plant death due to lack of rain after germination. These deaths are similar to those observed by Abbott and Roundy (2003) who found two sowing dates in two separate years where the drying front exceeded seminal root depth for native perennial grasses. The complexity comes in because their field data did not show $100 \%$ mortality but instead had $0.6 \%$ and $7.9 \%$ survival. While this may not result in a stand of vegetation that allows one to claim reclamation success, even with sufficient water, survival rates of native perennial grasses are not near $100 \%$ in arid and semi-arid areas. With 32 days of available water (the drying front did not exceed the seminal root depth), there was $28 \%$ survival of B. curtipendula, $27 \%$ survival of L. dubia, $10 \%$ survival of D. californica, and $11 \%$ survival of $E$. 


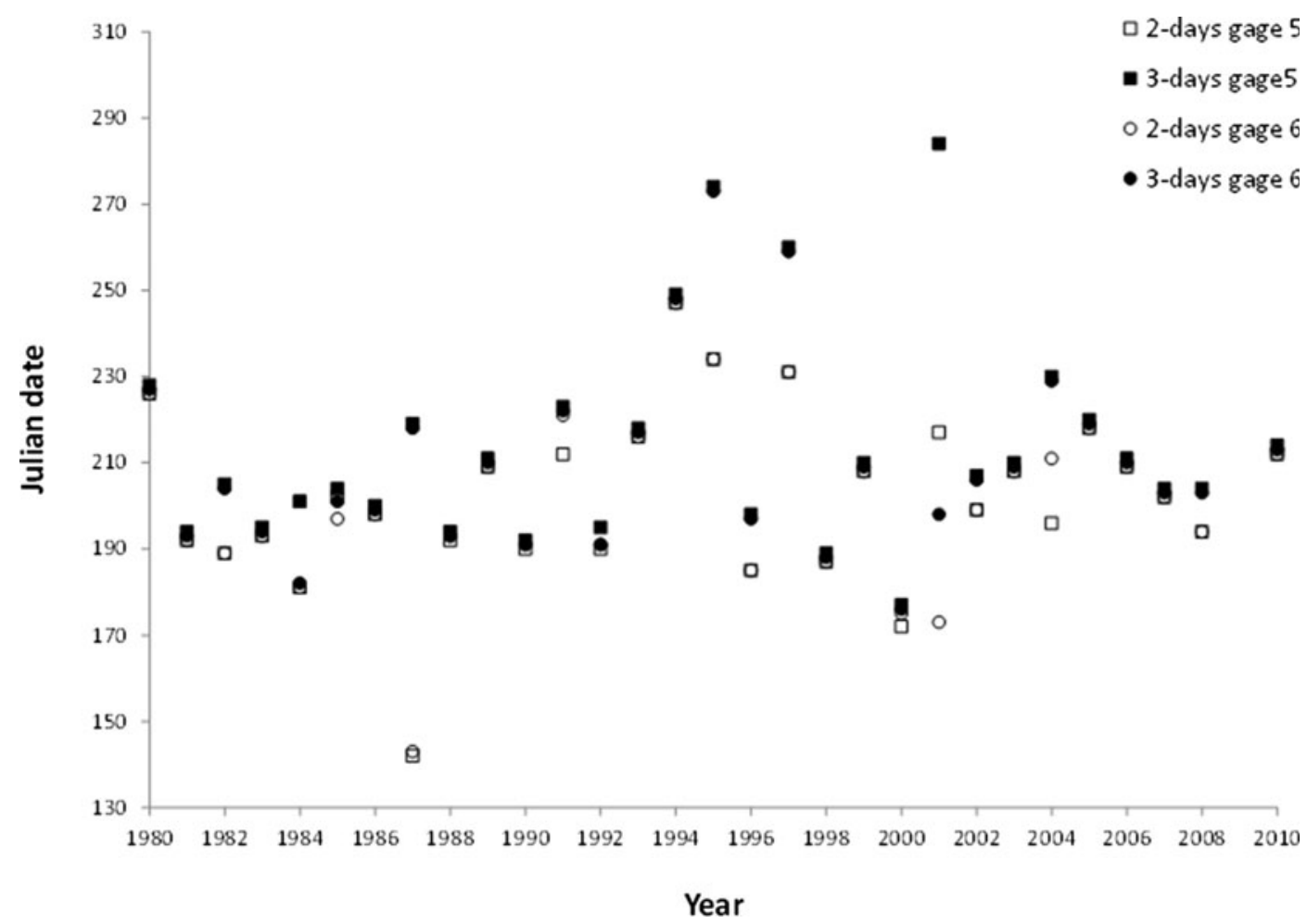

Fig. 1 Graph of the germination dates by year from 1980 to 2010 . Julian date 150 is 29 May, 200 is 18 July, and 250 is 6 Sept

intermedia (Abbott and Roundy 2003). Nor are low survival rates unique to Arizona. In a study in Wyoming, Chambers (2000) found an overall survival rate of $1 \%$ for seeded plants. Pyke (1990) had less than $1 \%$ on a study in Utah, and James et al. (2011) had less than $9 \%$ in Oregon. Given the relatively low survival rates of these common native perennial grasses, small differences may be more important than they appear, although poor survival possibly can be managed in the field by increasing the seeding rate or changing seed sources to more drought-tolerant collections.

The bottleneck for revegetation appears to be primarily in the establishment phase which occurs in the weeks following germination. This appears applicable across many different systems, including Minnesota (Fay and Shultz 2009), Utah (Pyke 1990), and New Mexico (Peters 2000), although other studies from Wyoming (Chambers 2000) and Oregon (James et al. 2011) found out that mortality primarily occurred between germination and emergence.

In the period after germination, elongation rate of the seminal root and adventitious root initiation are the important factors for survival. B. curtipendula averaged about $0.8 \mathrm{~cm}$ per day of seminal root elongation, but the lengths varied $0.5-1.1 \mathrm{~cm}$ per day, depending on the amount and frequency of water with faster
Table 5 The overlap (consistency) among establishment failure across the gages and germination scenarios

\begin{tabular}{|c|c|c|c|c|c|c|}
\hline & & & \multicolumn{2}{|c|}{ Gage 5 site } & \multicolumn{2}{|c|}{ Gage 6 site } \\
\hline & & & 2-day & 3-day & 2-day & 3-day \\
\hline & & Failures & 11 & 9 & 9 & 11 \\
\hline \multirow[t]{4}{*}{ Overlap } & Gage 5 site & 2-day & - & 6 & 9 & 6 \\
\hline & & 3-day & 6 & - & 5 & 8 \\
\hline & Gage 6 site & 2-day & 9 & 5 & - & 4 \\
\hline & & 3-day & 6 & 8 & 4 & - \\
\hline \multicolumn{3}{|c|}{ Average germination date } & $20 \mathrm{Jul}$ & 1 Aug & $19 \mathrm{Jul}$ & $27 \mathrm{Jul}$ \\
\hline
\end{tabular}


elongation associated with more water (Roundy et al. 1993). For B. curtipendula, adventitious roots initiated on day 9 when watered every 3 days compared with day 13 when only watered on days 1 and 7 (Roundy et al. 1993). This would trigger the need for $2-4$ days of available surface moisture to foster adventitious root elongation. B. gracilis is similar in that it needs wet conditions $2-8$ weeks after germination to allow adventitious root establishment (Frasier et al. 1984). The variability of root elongation rates, the lack of studies on the non-genetic causes of rate differences, and inherent real-world variability in soil conditions make it difficult to know how they would change the outcome of our analysis.

Hovenden et al. (2008) found that the primary driver of seedling survivorship in a climate change scenario was soil moisture and that warming and $\mathrm{CO}_{2}$ increases only affected survivorship indirectly through changing soil moisture. Notaro et al. (2012) predicted that southern Arizona will have warmer and dryer weather in the future but that much of this will be decreased winter precipitation which may have a limited impact on the dominant warmseason (C4) perennial grasses such as those modeled in this study. Consistent with Perring and Hovenden (2012), the total annual rainfall appears only slightly correlated with our predicted seeding success or failure. A logistic regression analysis showed that total seasonal precipitation was a significant predictor of germination success $(p=0.027)$, but the analysis accounted for little of the variability (Nagelkerke $R^{2}=0.059$ ). The 6 years with the lowest rainfall (below $300 \mathrm{~mm}$ compared with a $400 \mathrm{~mm}$ average) had a $50 \%$ failure rate which is more than the average rate of $32 \%$. The six years with the highest observed average rainfall (above $465 \mathrm{~mm}$ ) had a $33 \%$ failure rate. The distribution of rainfall events is clearly a variable that benefits seeds or seedlings, but larger event sizes during the growing season might not increase establishment. Once a storm event saturates the soil, a higher intensity event may not benefit seedling establishment because the seedlings are unable access moisture which has infiltrated deeper in the soil column and the excess water is lost as runoff. Plant establishment is sensitive to small changes in rainfall timing which is not well specified in predictions of future rainfall. Our observation of the common presence of events conducive to seeding success across the range of annual rainfall values makes it appear that warmseason perennial grasses may not be at risk from the kinds of changes predicted by Notaro et al. (2012).
The overall management implication for this study is that funds for reseeding must be available for at least a second year. This will allow reseeding the following year if there is a reclamation failure the year before. Further funds/reseeding effort may be needed because seeding failure 3 years in a row appears possible. A variety of species in a diverse mix, while often recommended for creation of a stable and self-sustaining plant community, may also help reduce the risk of seeding failure in years with marginally poor rainfall distribution because different species have different water and time requirements for germination. Field experiments would verify the germination and establishment modeling results and allow better predictions of seeding success.

Acknowledgments The Rosemont Copper Company funded this research.

Open Access This article is distributed under the terms of the Creative Commons Attribution License which permits any use, distribution, and reproduction in any medium, provided the original author(s) and the source are credited.

\section{References}

Abbott, L. B., \& Roundy, B. A. (2003). Available water influences field germination and recruitment of seeded grasses. Journal of Range Management, 56, 56-64.

Banerjee, M. J., Gerhart, V. J., \& Glenn, E. P. (2006). Native plant regeneration on abandoned desert farmland: Effects of irrigation, soil preparation, and amendments on seedling establishment. Restoration Ecology, 14, 339-348.

Carren, C. J., Wilson, A. M., Cuany, R. L., \& Thor, G. L. (1987). Caryopsis weight and planting depth of Blue Grama. I. Morphology, emergence, and seedling growth. Journal of Range Management, 40, 207-211.

Chambers, J. (2000). Seed movements and seedling fates in disturbed sagebrush steppe ecosystems: Implications for restoration. Ecological Applications, 10, 1400-1413.

Clapp, R. B., \& Hornberger, G. M. (1978). Empirical equations for some soil hydraulic properties. Water Resources Research, 14, 601-604.

Cox, J. R., \& Jordan, G. L. (1983). Density and production of seeded range grasses in southeastern Arizona (1970-1982). Journal of Range Management, 36, 649-652.

D'Antonio, C. D., \& Meyerson, L. A. (2002). Exotic plant species as problems and solutions in ecological restoration: A synthesis. Restoration Ecology, 10, 703-713.

De Baets, S., Poesen, J., Reubens, B., Muys, B., De Baerdemaeker, J., \& Meersmans, J. (2009). Methodological framework to select plant species for controlling rill and gully erosion: Application to a Mediterranean ecosystem. Earth Surface Processes and Landforms, 34, 1374-1392. 
Emmerich, W. E., \& Hardegree, S. P. (1996). Partial and full dehydration impact on germination of 4 warm-season grasses. Journal of Range Management, 49, 355-360.

Fay, P. A., \& Shultz, M. J. (2009). Germination, survival, and growth of grass and forb seedlings: Effects of soil moisture variability. Acta Oecologica, 35, 679-684.

Fehmi, J. S., \& Kong, T. M. (2012). Effects of soil type, rainfall, straw mulch, and fertilizer on semi-arid vegetation establishment, growth and diversity. Ecological Engineering, 44, 70-77.

Fehmi, J. S., Hammond, M., \& Bartolome, J. W. (2008). Alignment of elongated Nassella pulchra plants with hill-slope contours. Arid Land Research and Management, 22, 212-215.

Flerchinger, G. N., \& Hardegree, S. P. (2004). Modelling near surface soil temperature and moisture for germination response predictions of post-wildfire seedbeds. Journal of Arid Environments, 59, 369-385.

Frasier, G. W., Woolhiser, D. A., \& Cox, J. R. (1984). Emergence and seedling survival of two warm-season grasses as influenced by the timing of precipitation: A greenhouse study. Journal of Range Management, 37, 7-11.

Frasier, G. W., Cox, J. R., \& Woolhiser, D. A. (1985). Emergence and survival response of seven grasses of six wet-dry sequences. Journal of Range Management, 38, 372-377.

Goodrich, D. C., Keefer, T. O., Unkrich, C. L., Nichols, M. H., Osborn, H. B., Stone, J. J., \& Smith, J. R. (2008). Long-term precipitation database, Walnut Gulch Experimental Watershed, Arizona, United States. Water Resources Research, 44, W05S04. doi:10.1029/2006WR005782.

Guiterrez, J., \& Hernandez, I. I. (1996). Runoff and interrill erosion as affected by grass cover in a semi-arid rangeland of northern Mexico. Journal of Arid Environments, 34, 287-295.

Hands, D. E., \& Brown, R. D. (2002). Enhancing visual preference of ecological rehabilitation sites. Landscape and Urban Planning, $58,57-70$.

Hardegree, S. P., Moffet, C. A., Roundy, B. A., Jones, T. A., Novak, S. J., Clark, P. E., Pierson, F. B., \& Flerchinger, G. N. (2010). A comparison of cumulative-germination response of cheatgrass (Bromus tectorum L.) and five perennial bunchgrass species to simulated field-temperature regimes. Environmental and Experimental Botany, 69, 320-327.

Hobbs, R. J., \& Cramer, V. A. (2008). Restoration ecology: Interventionist approaches for restoring and maintaining ecosystem function in the face of rapid environmental change. Annual Review of Environment and Resources, 33, 39-61.

Hovenden, M. J., Newton, P. C. D., Wills, K. E., Janes, J. K., Williams, A. L., Vander Schoor, J. K., \& Nolan, M. J. (2008). Influence of warming on soil water potential controls seedling mortality in perennial but not annual species in a temperate grassland. New Phytologist, 180, 143-152.

Hyder, D. N., Everson, A. C., \& Bement, R. E. (1971). Seedling morphology and seedling failures with blue grama. Journal of Range Management, 24, 287-292.

James, J. J., Svejcar, T. J., \& Rinella, M. J. (2011). Demographic processes limiting seedling recruitment in arid grassland restoration. Journal of Applied Ecology, 48, 961-969.

Josa, R., Jorba, M., \& Vallejo, V. R. (2012). Opencast mine restoration in a Mediterranean semi-arid environment:
Failure of some common practices. Ecological Engineering, 42, 183-191.

Laio, F., Porporato, A., Ridolfi, L., \& Rodriguez-Iturbe, I. (2001). Plants in water-controlled ecosystems: Active role in hydrologic processes and response to water stress II. Probabilistic soil moisture dynamics. Advances in Water Resources, 24, 707-723.

McDonald, C. J., \& McPherson, G. R. (2011). Fire behavior characteristics of buffelgrass-fueled fires and native plant community composition in invaded patches. Journal of Arid Environments, $75,1147-1154$.

Mitchell, K. E., Lohmann, D., Houser, P. R., Wood, E. F., Schaake, J. C., Robock, A., Cosgrove, B. A., Sheffield, J., Duan, Q., Luo, L., Higgins, R. W., Pinker, R. T., Tarpley, J. D., Lettenmaier, D. P., Marshall, C. H., Entin, J. K., Pan, M., Shi, W., Koren, V., Meng, J., Ramsay, B. H., \& Bailey, A. A. (2004). The multi-institution North American Land Data Assimilation System (NLDAS): Utilizing multiple GCIP products and partners in a continental distributed hydrological modeling system. Journal of Geophysical Research, 109, D07S90. doi:10.1029/2003JD003823.

Niu, G.-Y., Sun, S.-F., \& Hong, Z.-X. (1997). Water and heat transport in the desert soil and atmospheric boundary layer in Western China. Boundary Layer Meteorology, 85, 179-195.

Niu, G.-Y., Yang, Z.-L., Mitchell, K. E., Chen, F., Ek, M. B., Barlage, M., Longuevergne, L., Kumar, A., Manning, K., Niyogi, D., Rosero, E., Tewari, M., \& Xia, Y.-L. (2011). The community Noah land surface model with multi-physics options, part 1: Model descriptions and evaluation with local-scale measurements. Journal of Geophysical Research, 116, D12109. doi:10.1029/2010JD015139.

Notaro, M., Mauss, A., \& Williams, J. W. (2012). Projected vegetation changes for the American Southwest: Combined dynamic modeling and bioclimatic-envelope approach. Ecological Applications, 22, 1365-1388.

Peppin, D. L., Fule, P. Z., Hull Sieg, C., Beyers, J. L., Hunter, M. E., \& Robichaud, P. R. (2011). Recent trends in post-wildfire seeding in western US forests: Costs and seed mixes. International Journal of Wildland Fire, 20, 702-708.

Perring, M. P., \& Hovenden, M. J. (2012). Seedling survivorship of temperate grassland perennials is remarkably resistant to projected changes in rainfall. Australian Journal of Botany, 60, 328-339.

Peters, D. P. C. (2000). Climatic variation and simulated patterns in seedling establishment of two dominant grasses at a semi-arid-arid grassland ecotone. Journal of Vegetation Science, 11, 493-504.

Pyke, D. A. (1990). Comparative demography of co-occurring introduced and native tussock grasses: Persistence and potential expansion. Oecologia, 82, 537-543.

Quijas, S., Schmid, B., \& Balvanera, P. (2010). Plant diversity enhances provision of ecosystem services: A new synthesis. Basic and Applied Ecology, 11, 582-593.

Roundy, B. A., \& Biedenbender, S. H. (1996). Germination of warm-season grasses under constant and dynamic temperatures. Journal of Range Management, 49, 425-431.

Roundy, B. A., Winkel, V. K., Cox, J. R., Dobrenz, A. K., \& Tewolde, H. (1993). Sowing depth and soil water effects on seedling emergence and root morphology of three warmseason grasses. Agronomy Journal, 85, 975-982. 
Roundy, B. A., Abbott, L. B., \& Livingston, M. (1997). Surface soil water loss after summer rainfall in a semidesert grassland. Arid Soil Research and Rehabilitation, 11, 49-62.

Roundy, B. A., Heydari, H., Watson, C., Smith, S. E., Munda, B., \& Pater, M. (2001). Summer establishment of Sonoran desert species for revegetation of abandoned farmland using line source sprinkler irrigation. Arid Land Research and Management, 15, 23-39.

Scott, R. L., Jenerette, G. D., Potts, D. L., \& Huxman, T. E. (2009). Effects of seasonal drought on net carbon dioxide exchange from a woody-plant-encroached semiarid grassland. Journal of Geophysical Research, 114, G04004.

Simanton, J. R., \& Jordan, G. (1986). Early root and shoot elongation of selected warm-season perennial grasses. Journal of Range Management, 39, 63-67.

Smith, S. E., Riley, E., Tiss, J. L., \& Fendenheim, D. M. (2000). Geographical variation in predictive seedling emergence in a perennial desert grass. Journal of Ecology, 88, 139-149.

Steinke, D. R., \& Majak, W. (2010). Cattle can tolerate highmolybdenum forage grown on reclaimed mine tailings: A review. International Journal of Mining, Reclamation and Environment, 24, 255-266.
Svobodova, K., Sklenickab, P., Molnarovab, K., \& Salekc, M. (2012). Visual preferences for physical attributes of mining and postmining landscapes with respect to the sociodemographic characteristics of respondents. Ecological Engineering, 43, 34- 44.

Thapa, R., Kemp, D. R., \& Mitchell, M. L. (2012). Climatic conditions for seedling recruitment within perennial grass swards in south-eastern Australia. Crop and Pasture Science, 63, 389-398.

Wilson, A. M., \& Briske, D. D. (1979). Seminal and adventitious root growth of blue grama seedlings. Agronomy Journal, $68,479-484$.

Woods, S. R., Fehmi, J. S., \& Backer, D. M. (2012). An assessment of revegetation treatments following removal of invasive Pennisetum ciliare (buffelgrass). Journal of Arid Environments, 87, 168-175.

Wuest, S. (2007). Vapour is the principal source of water imbibed by seeds in unsaturated soils. Seed Science Research, 17, 3-9.

Zimmerman, J., Higgens, S. I., Grimm, V., Hoffmann, J., Munkemuller, T., \& Linstadter, A. (2008). Recruitment filters in a perennial grassland: The interactive roles of fire, competitors, moisture and seed availability. Journal of Ecology, 96, 1033-1044. 